\title{
Bioarchaeological evidence for conflict in Iron Age north-west Cambodia
}

\author{
K.M. Domett ${ }^{1}$, D.J.W. O’Reilly ${ }^{2}$ \& H.R. Buckley ${ }^{3}$
}

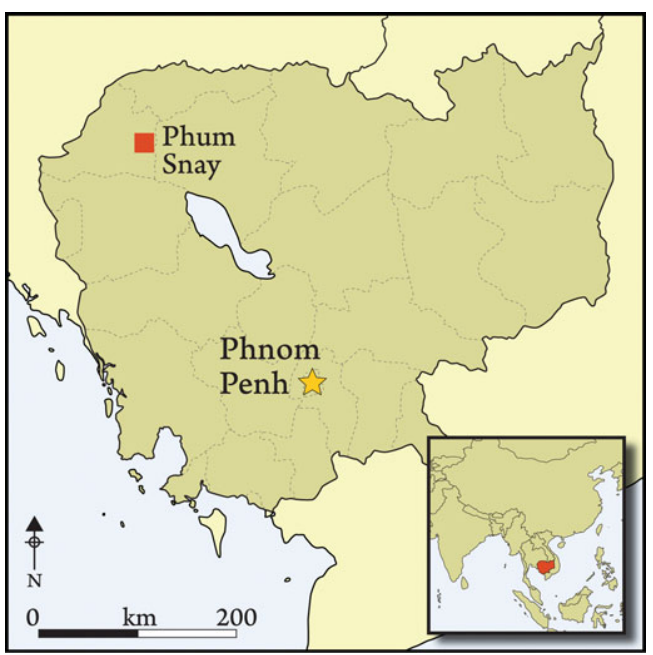

Examination of skeletal material from graves at Phum Snay in north-west Cambodia revealed an exceptionally high number of injuries, especially to the head, likely to have been caused by interpersonal violence. The graves also contain a quantity of swords and other offensive weapons used in conflict. The authors propose a context for these warriors in the struggle between emergent polities in the Iron Age before the domination of Angkor.

Keywords: Cambodia, Angkor, Phum Snay, Iron Age, conflict, cemeteries

\section{Introduction}

There is considerable evidence for conflict and the imposition of hegemony by one group over another in Southeast Asia from earliest times. From the Angkor period (after AD 800), there is ample evidence of conflict, both from inscriptions (Finot 1925; Jacques 1986) and bas-reliefs (Coedés 1932; Le Bonheur \& Poncar 1993; Chetwin 2001; Clark 2007; Jacq-Hergoualc'h 2007). Accounts from Chinese histories also provide indirect evidence of conflict in the earlier period. One indicates that settlements in the polity of Funan, located in the Mekong delta, were fortified. Another reveals that missions were sent to China by a number of polities conquered by Chenla, the power that superseded Funan in Cambodia, after AD 650-56 (Tuan-Lin 1876).

1 Department of Anatomy and Pathology, School of Medicine and Dentistry, James Cook University, Townsville, QLD 4811, Australia (Email: kate.domett@jcu.edu.au)

2 Department of Archaeology, SOPHI, University of Sydney, Camperdown 2006, NSW, Australia

3 Department of Anatomy and Structural Biology, School of Medical Sciences, University of Otago, Dunedin, New Zealand 
A number of interpretations for the locations of these polities have been proposed (Aymonier 1904; Gerini 1909; Briggs 1951; Wheatley 1961; Coedés 1968). Wolters (1974), using inscriptions from Coedés (1937-66), argues that north-west Cambodia is the most likely. He hypothesises that the natural environment of north-west Cambodia would have encouraged the formation of independent polities, centred, perhaps, on small hills. Given the evidence at hand it would seem that north-west Cambodia may have witnessed a considerable degree of political friction, and this has now been endorsed by a detailed bioarchaeological examination of human remains found at Phum Snay, which is reported here. Modern bioarchaeological studies from Cambodia have been advanced recently by virtue of new large-scale archaeological projects (Stark 2004; O'Reilly et al. 2006b; Pietrusewsky et al. 2006; Evans et al. 2007; Domett \& O'Reilly 2009). The present study has provided an opportunity to significantly increase our understanding of the lifestyle of a pre-Angkorian Cambodian population and assess the level of social tension at the time.

\section{The site}

Phum Snay is located approximately $80 \mathrm{~km}$ to the north-west of Angkor (Figure 1). Excavations there were led by O'Reilly and carried out in collaboration with the Royal University of Fine Arts, Phnom Penh from 2001 to 2003. Archaeological and general skeletal analyses on this material have been reported previously (O'Reilly \& Pheng 2001; O'Reilly et al. 2004, 2006a \& b; Domett \& O’Reilly 2009). A large collection of unprovenanced skeletal material was also identified, the by-product of looting as burials were disturbed during the search for valuable artefacts. Although stratigraphically unprovenanced and anatomically dislocated these remains come from Phum Snay and are likely to be from a similar time period (c. 350 BC-AD 200) as the prehistoric cemetery appears to have had a brief span of use (O'Reilly et al. 2006b).

The excavation of Phum Snay also yielded evidence of military paraphernalia (swords, daggers, spearheads, projectile points, epaulettes) in the prehistoric graves. This fact, in conjunction with the site's proximity to the later Angkorian capital, may be suggestive of increased competition over resources driving the development of strongly hierarchical societies that eventually led to state rule in the region (O'Reilly et al. 2006b). This study tests whether there was also evidence of interpersonal violence in the human skeletal remains.

\section{Method}

Research at Phum Snay yielded 21 excavated burials containing human bone (Domett \& O'Reilly 2009) and an extensive collection of stratigraphically unprovenanced skeletal material from Phum Snay. The minimum number of individuals (MNI) was 134: 124 adults and 10 sub-adults. The latter remains were collected from pits produced by looting around the village and are now stored at Wat Leu in Phum Snay and Wat Rajabo in Siem Reap.

Age-at-death estimation was obtained using standard methods prioritising late fusing epiphyses, pubic symphysis morphology and dental wear in the adult remains (no trauma was evident in sub-adults) (Buikstra \& Ubelaker 1994; Domett \& O’Reilly 2009). Sex determination relied predominantly on pelvic and cranial morphology following Buikstra 


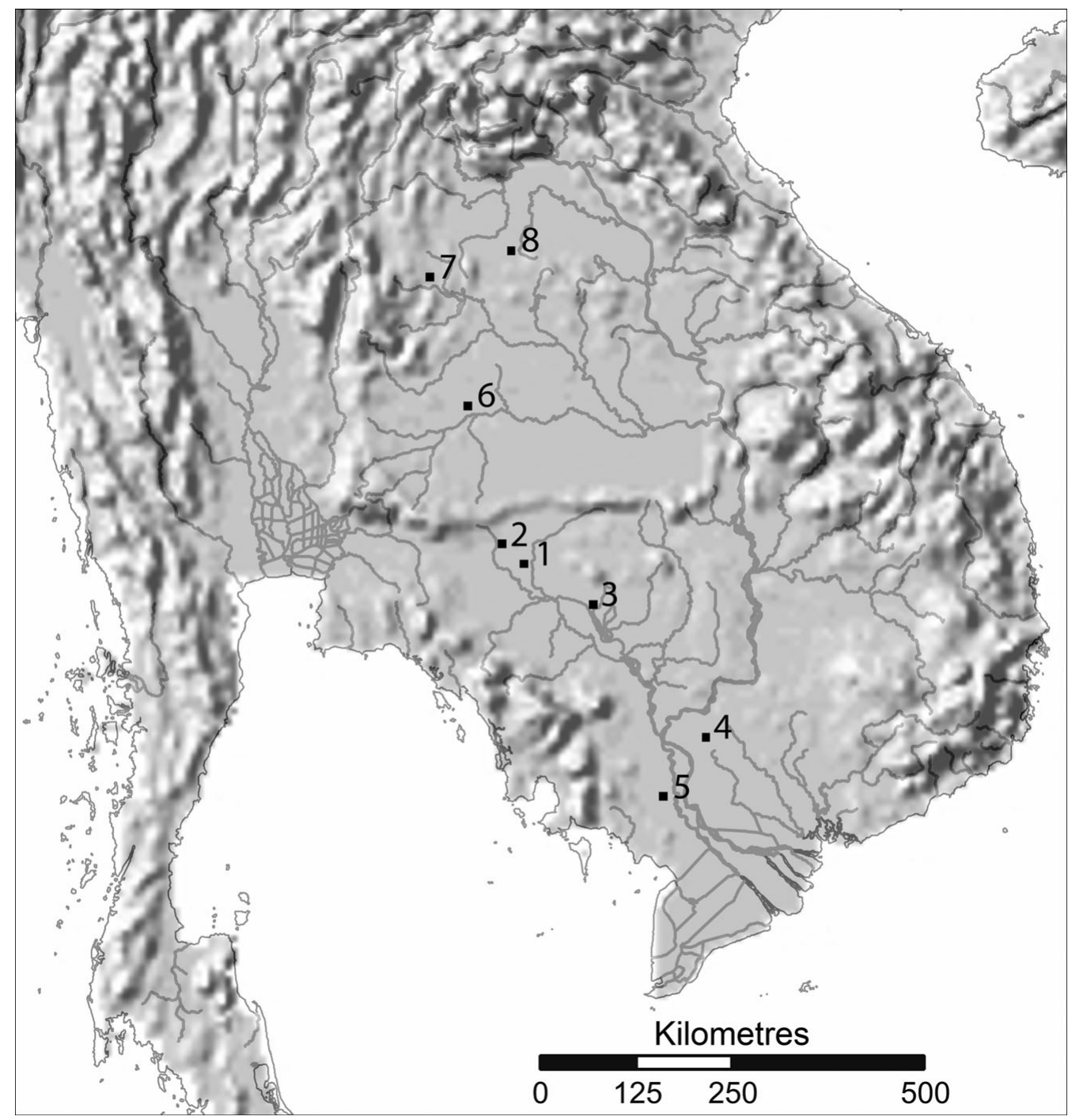

Figure 1. Map of Southeast Asia indicating sites mentioned in the text. Cambodia: 1) Phum Snay; 2) Koh Krabas; 3) Angkor; 4) Prohear; 5) Angkor Borei; Thailand: 6) Ban Non Wat and Noen U-Loke; 7) Non Nok Tha; 8) Ban Chiang.

and Ubelaker (1994). During the general analysis of all skeletal elements, detailed descriptive and photographic recording of all pathological lesions was undertaken. Radiography was undertaken of some specimens with pathology but the images were not clear given the limited facilities in Siem Reap and the amount of post-depositional soil in the remains.

This study presents the results of an examination of lesions (pathology) believed to have been caused by trauma (physical injury). Traumatic lesions vary widely in their morphology but can usually be readily distinguished from other types of pathology, such as infectious or neoplastic diseases (Ortner 2003). Cranial injuries were classified either as depression fractures from blunt force trauma (BFT), or sharp force trauma (SFT) leading to punctures 
Table 1. The age and sex structure of the Phum Snay sample analysed.

\begin{tabular}{lcccc}
\hline & Male & Female & ?sex & Total \\
\hline Young adult & 6 & 9 & 2 & $17(13.3 \%)$ \\
Middle aged adult & 8 & 4 & 2 & $14(10.9 \%)$ \\
Older adult & 6 & 2 & 0 & $8(6.3 \%)$ \\
Adult & 38 & 40 & 11 & $89(69.5 \%)$ \\
Total & $58(45.3 \%)$ & $55(43.0 \%)$ & $15(11.7 \%)$ & 128 \\
\hline
\end{tabular}

Male $v$ f female age structure $\mathrm{Chi}^{2} \mathrm{p}$-value $=0.1341$, n.s

or cut marks (Byers 2002). Depression fractures in the cranium are characterised by a circular fracture of the outer layer of compact bone causing a depression in the bone at the point of impact. On remodelling (healing), a circular depression remains on the outer surface (Lovell 1997; Ortner 2003). Clinical examples show that depression fractures may be created in bone as the result of hammer blows and/or falls onto sharp edged objects (Lovell 1997). BFT is less likely to result in death compared to SFT (Kaufman et al. 1997).

SFT usually creates a lesion with a small, discrete, linear or circular focus (Byers 2002; Lovell 2008). The appearance of the lesion can vary, depending on the angle at which the force is applied and the weapon used. Knives, swords, axes or anything with a sharp edge or point are a common cause of SFT (Byers 2002).

Unhealed injuries that occur around the time of death (perimortem trauma) can be difficult to differentiate from postmortem breakage of bone. Perimortem fractures may be identified by observing the form of the lesion edges, colouration and fracture lines (Quatrehomme \& İşcan 1997; Walker 2001). The presence of flakes of bone still adhering to the fracture edges can also indicate perimortem trauma because the organic content remaining in the tissue prevented the bone from breaking completely (Ortner 2003; Stodder 2008).

\section{Results}

Table 1 indicates the age and sex structure of the analysed sample. There were no significant differences between the age structure of males and females. A total of 30 individuals $(23.4$ per cent) displayed evidence of traumatic lesions (Table 2). Among all individuals demonstrating a lesion, more than twice as many males as females were affected. There were 39 lesions observed, with seven individuals (two females, five males) having two or more lesions each. Significantly more lesions were observed in males than females and lesions were predominantly on the right-hand side but not to a statistically significant level (Table 3). The parietal bone was more commonly affected than the frontal or occipital bone. Frontal lesions were significantly more common in males than in females but there were no such sex differences between parietal lesions. Crania were equally affected by BFT and SFT (Table 4). Healed lesions were far more numerous than unhealed (perimortem) lesions (Table 4).

Seventeen BFT lesions, in the form of healed depression fractures, were seen in 15 individuals: two males had two lesions each (Table 5). These oval or circular lesions ranged in diameter from 4-22 $\mathrm{mm}$ (Figure 2). BFT lesions were confined to the parietal and frontal 
Table 2. Age and sex distribution of those with cranial trauma at Phum Snay.

\begin{tabular}{lcccc}
\hline & $\mathrm{N}$ (individuals) & $\%$ & $\mathrm{~N}$ (lesions) & $\%$ \\
\hline Males & 19 & 63.3 & 24 & 61.6 \\
Females & 9 & 30.0 & 13 & 33.3 \\
? sex & 2 & 6.7 & 2 & 5.1 \\
Total & 30 & 100 & 39 & 100 \\
\hline
\end{tabular}

Male $v$ s female (by individual) $\mathrm{Chi}^{2} \mathrm{p}$-value $=0.0075$, sign $^{* *}$

Male $v$ f female (by lesion) $\mathrm{Chi}^{2} \mathrm{p}$-value $=0.0105$, sign ${ }^{* *}$

Table 3. The location of lesions (healed and perimortem) in the crania of Phum Snay.

\begin{tabular}{lccccc}
\hline & & Male & Female & ?sex & Total \\
\hline Frontal & Left & 2 & 1 & 0 & 3 \\
& Centre & 0 & 1 & 0 & 1 \\
& Right & 8 & 0 & 1 & 9 \\
& Total & $10(76.9 \%)$ & $2(15.4 \%)$ & $1(7.7 \%)$ & $13(33.3 \%)$ \\
Parietal & Left & 7 & 5 & 0 & 12 \\
& Right & 7 & 5 & 1 & 13 \\
& Total & $14(56.0 \%)$ & $10(40.0 \%)$ & $1(4.0 \%)$ & $25(64.1 \%)$ \\
Occipital & Left & 0 & 1 & 0 & 1 \\
\multirow{5}{*}{ Total } & Total & 0 & 1 & 0 & $1(2.6 \%)$ \\
& Left & 9 & 7 & 0 & $16(41.0 \%)$ \\
& Centre & 0 & 1 & 0 & $1(2.6 \%)$ \\
& Right & 15 & 5 & 2 & $22(56.4 \%)$ \\
& Total & $24(61.6 \%)$ & $13(33.3 \%)$ & $2(5.1 \%)$ & 39 \\
\hline
\end{tabular}

Frontal lesions: males $v s$ females $\mathrm{Chi}^{2} \mathrm{p}$-value $=0.0011$, sign ${ }^{* *}$

Parietal lesions: males vs females $\mathrm{Chi}^{2}$ p-value $=0.2482$, n.s.

Parietal $v$ s frontal bone $\mathrm{Chi}^{2} \mathrm{p}$-value $=0.0059$, sign ${ }^{* *}$

Right $v$ s left (total) $\mathrm{Chi}^{2} \mathrm{p}$-value $=0.1687$, n.s.

Table 4. Types of cranial trauma at Phum Snay.

\begin{tabular}{lccc}
\hline & Healed lesions & Perimortem lesions & Total \\
\hline Blunt force trauma & 17 & 2 & $19(48.7 \%)$ \\
Sharp force trauma & 14 & $5^{\#}$ & $19(48.7 \%)$ \\
Other injury & 1 & & $1(2.6 \%)$ \\
Total & $32(82.0 \%)$ & $7(17.9 \%)$ & 39 \\
\hline
\end{tabular}

\# this includes WLC74 who had approximately four SFT lesions (see below).

Healed vs perimortem trauma $\mathrm{Chi}^{2}$ p-value $<0.0001$, sign ${ }^{* *}$

bones, with a predilection for the right side and for the parietal bone. There was a strong association of healed depression fractures with males.

Fourteen healed SFT lesions were seen in 12 individuals (Table 6). These lesions varied in length from $4-24 \mathrm{~mm}$ and were linear, slightly curved or notched (Figure 3). Most SFT was located on the parietal bone but no predilection for side or sex was evident. 
Table 5. Blunt force trauma lesions (healed) at Phum Snay.

\begin{tabular}{lccccc}
\hline & & Male & Female & ?sex & Total \\
\hline \multirow{2}{*}{ Frontal } & Left & 1 & 0 & 0 & 1 \\
& Right & 4 & 0 & 0 & 4 \\
& Total & 5 & 0 & 0 & $5(29.4 \%)$ \\
Parietal & Left & 4 & 1 & & 5 \\
& Right & 5 & 1 & 1 & 7 \\
& Total & 9 & 2 & 1 & $12(70.6 \%)$ \\
Total & Left & 5 & 1 & 0 & $6(35.3 \%)$ \\
& Right & 9 & 1 & 1 & $11(64.7 \%)$ \\
& Total & $14(82.3 \%)$ & $2(11.8 \%)$ & $1(5.9 \%)$ & 17 \\
\hline
\end{tabular}

Right $v$ s left (total) $\mathrm{Chi}^{2}$ p-value $=0.0863$, n.s.

Parietal $v$ frontal $\mathrm{Chi}^{2} \mathrm{p}$-value $=0.0164$, sign $^{* *}$

Male vs female (total) $\mathrm{Chi}^{2} \mathrm{p}$-value $<0.0001$, sign ${ }^{* *}$

Table 6. Sharp force trauma lesions (healed) at Phum Snay.

\begin{tabular}{lccccc}
\hline & & Male & Female & ?sex & Total \\
\hline \multirow{2}{*}{ Frontal } & Left & 1 & 1 & 0 & 2 \\
& Right & 1 & 1 & 0 & 2 \\
& Total & 2 & 2 & 0 & $4(28.6 \%)$ \\
Parietal & Left & 3 & 2 & 0 & 5 \\
& Right & 2 & 2 & 1 & 5 \\
& Total & 5 & 4 & 1 & $10(71.4 \%)$ \\
Total & Left & 4 & 3 & 0 & $7(50.0 \%)$ \\
& Right & 3 & 3 & 1 & $7(50.0 \%)$ \\
& Total & $7(50.0 \%)$ & $6(42.9 \%)$ & $1(7.1 \%)$ & 14 \\
\hline
\end{tabular}

Right $v$ s left (total) $\mathrm{Chi}^{2}$ p-value $=1.000$, n.s.

Parietal $v$ s frontal $\mathrm{Chi}^{2}$ p-value $=0.0233$, sign ${ }^{*}$

Male $v$ female (total) $\mathrm{Chi}^{2}$ p-value $=0.6949$, n.s.

A further healed lesion that may be attributable to trauma was evident in the grossly deformed right orbit of an adult male. There was extensive remodelling of the right frontal, zygomatic and maxillary bones (Figure 4). The widespread healing does make it difficult to confidently diagnose trauma as opposed to other causes of eye loss such as a neoplasm. It is almost certain that the eye had been lost during life.

Three further crania had perimortem lesions: one male and two females. The male had two lesions on the frontal bone: one large BFT (28mm in diameter) and one SFT puncture wound that likely indicates the mode of death. One of the female cases shows a probable perimortem depression fracture of the glabella (Figure 5). It would seem unlikely that this was a fatal lesion and some other injury sustained at the same time may have led to death.

The most severe perimortem trauma was evident in a further adult female. Multiple perimortem SFT lesions were evident running across the parietal and frontal bones (Figure 6). The largest lesion was on the right lateral side of the cranium involving the parietal, temporal and frontal bones (see Figure 6a for full explanation of lesions). It is possible that a large bladed instrument, greater than $c .80 \mathrm{~mm}$ in width, entered the cranium 


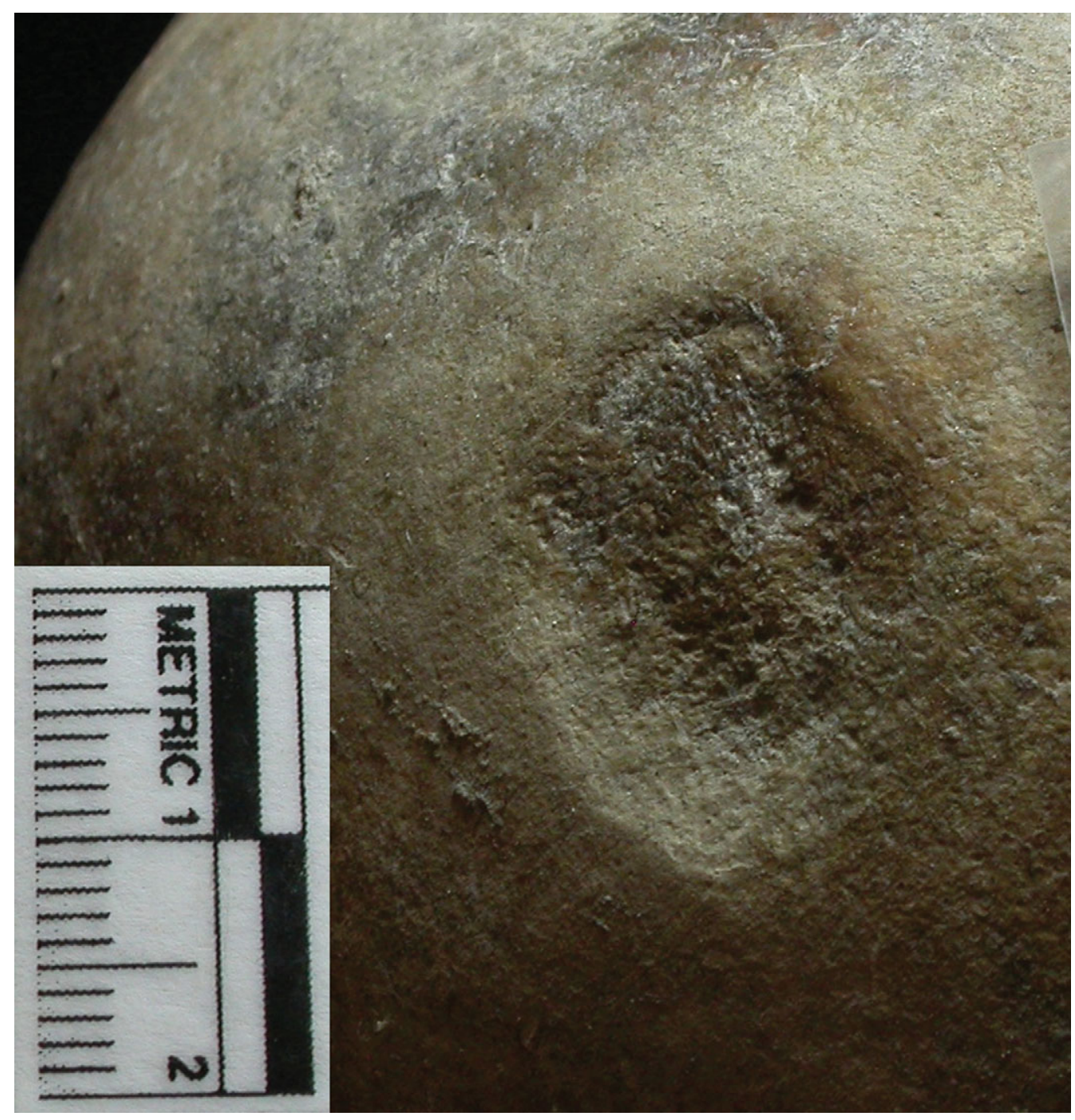

Figure 2. BFT: healed depression fracture on the posterior aspect of the left parietal bone (adult male).

on the right and protruded through to the left side where a smaller, unhealed lesion is visible (Figure 6b). There is also an unhealed cut mark on the left inferior occipital bone with an inner table flake missing just $23 \mathrm{~mm}$ from the foramen magnum in which the spinal cord runs, implying a reasonable amount of force was applied and could possibly be an attempted decapitation. This series of perimortem injuries suggests death by multiple blows to the head with a bladed instrument.

In the postcranial collection there were very few other fractures. Only minor, small diameter bones were affected including two right radii (unknown sex), three clavicles (one female, one male and one unknown sex), two possible fractures of mandibular condyles (unknown sex) and two hand bones (both female). 


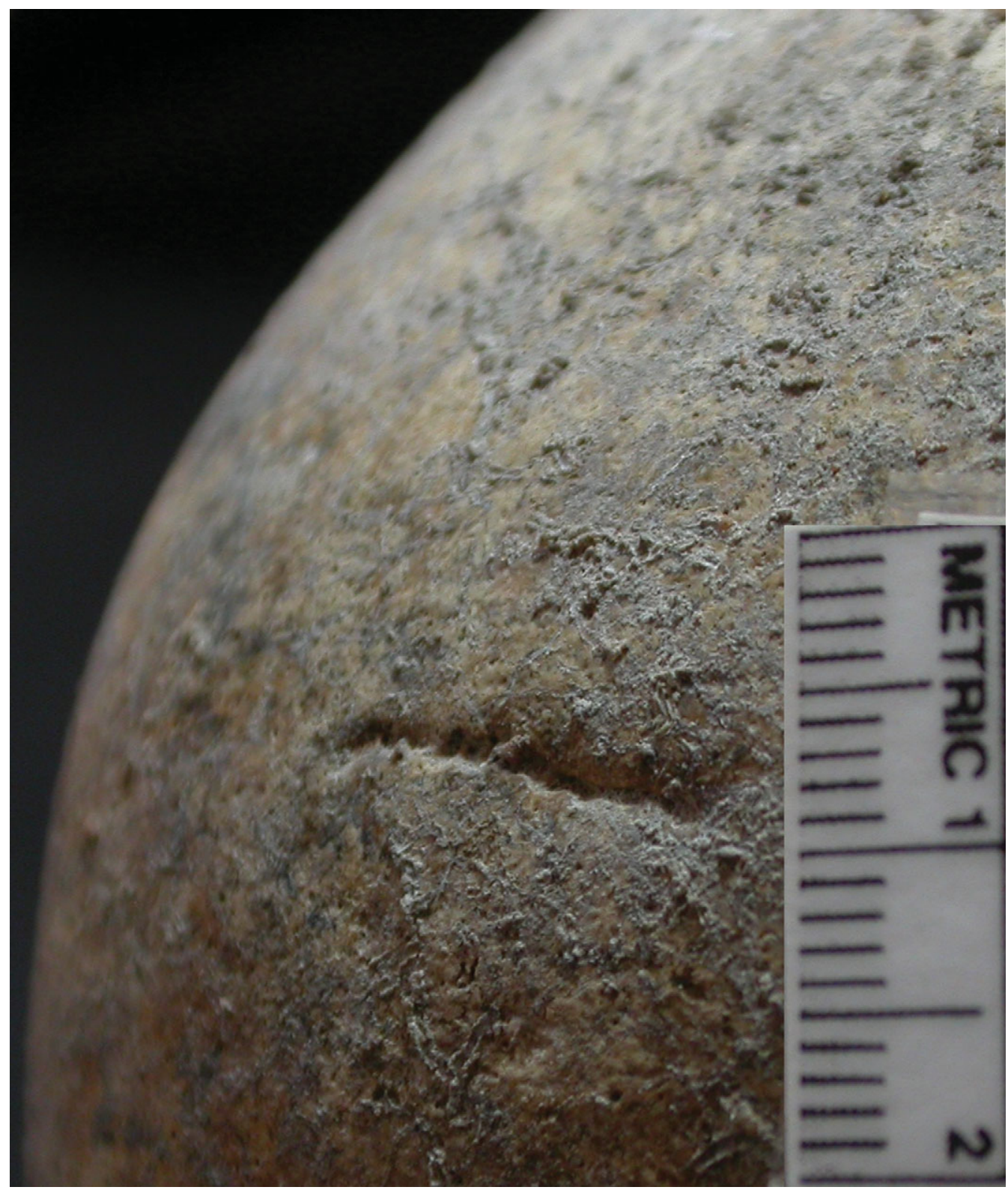

Figure 3. SFT: small, non-linear healed SFT on the left superior-posterior aspect of the left parietal (adult, ?male).

\section{Discussion}

The trauma seen in Phum Snay most likely has a violent aetiology (cause or origin). According to Lovell (1997), cranial trauma is more likely the result of interpersonal violence than any other type of fracture. This trauma may of course have resulted from domestic, ritual or politically motivated violence. But the high prevalence of trauma at the site, the frequency of trauma in males and the contextual information suggest the presence of warfare 
K.M. Domett et al.

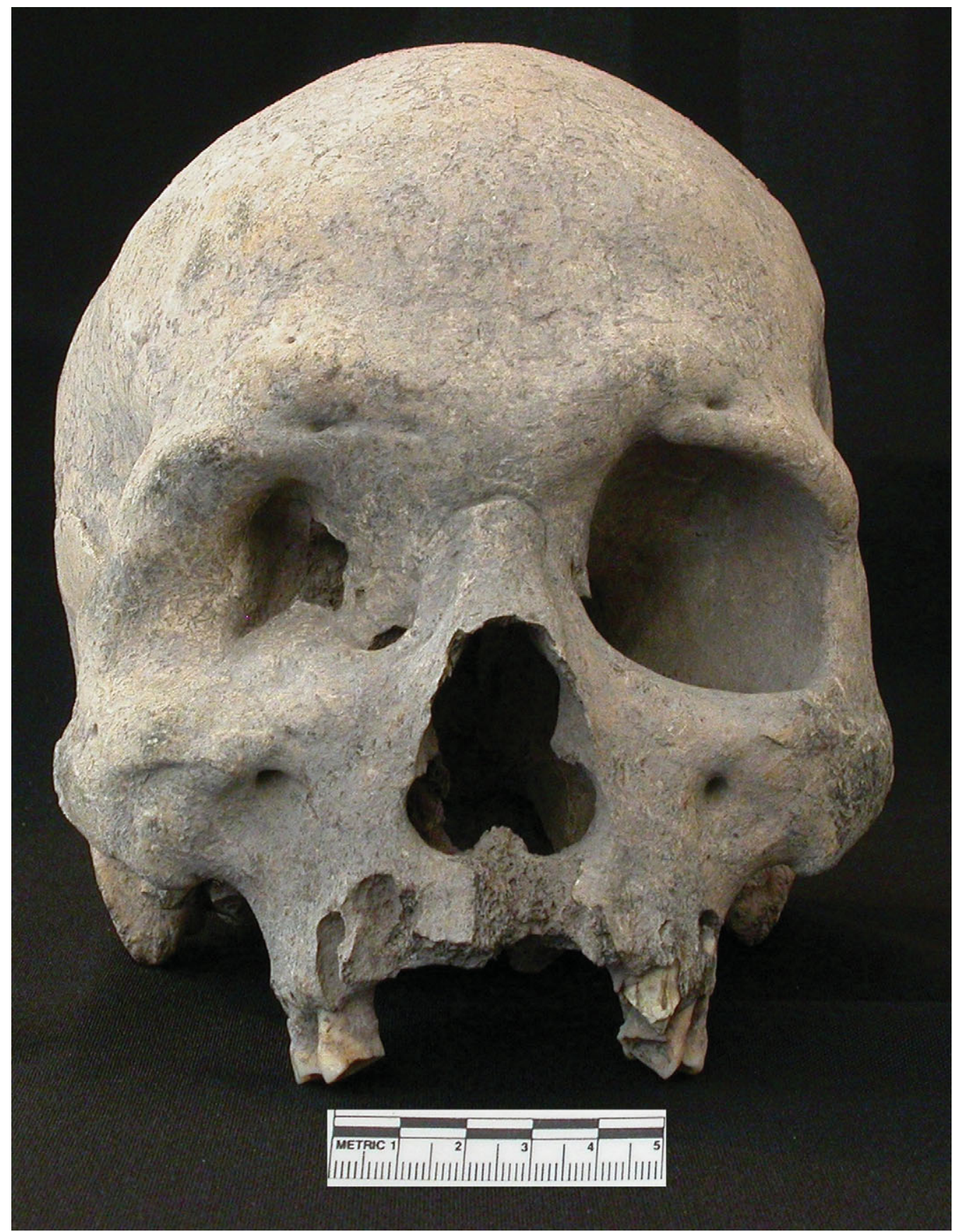

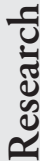

Figure 4. Deformation with bone remodelling of the right orbit (adult male). 


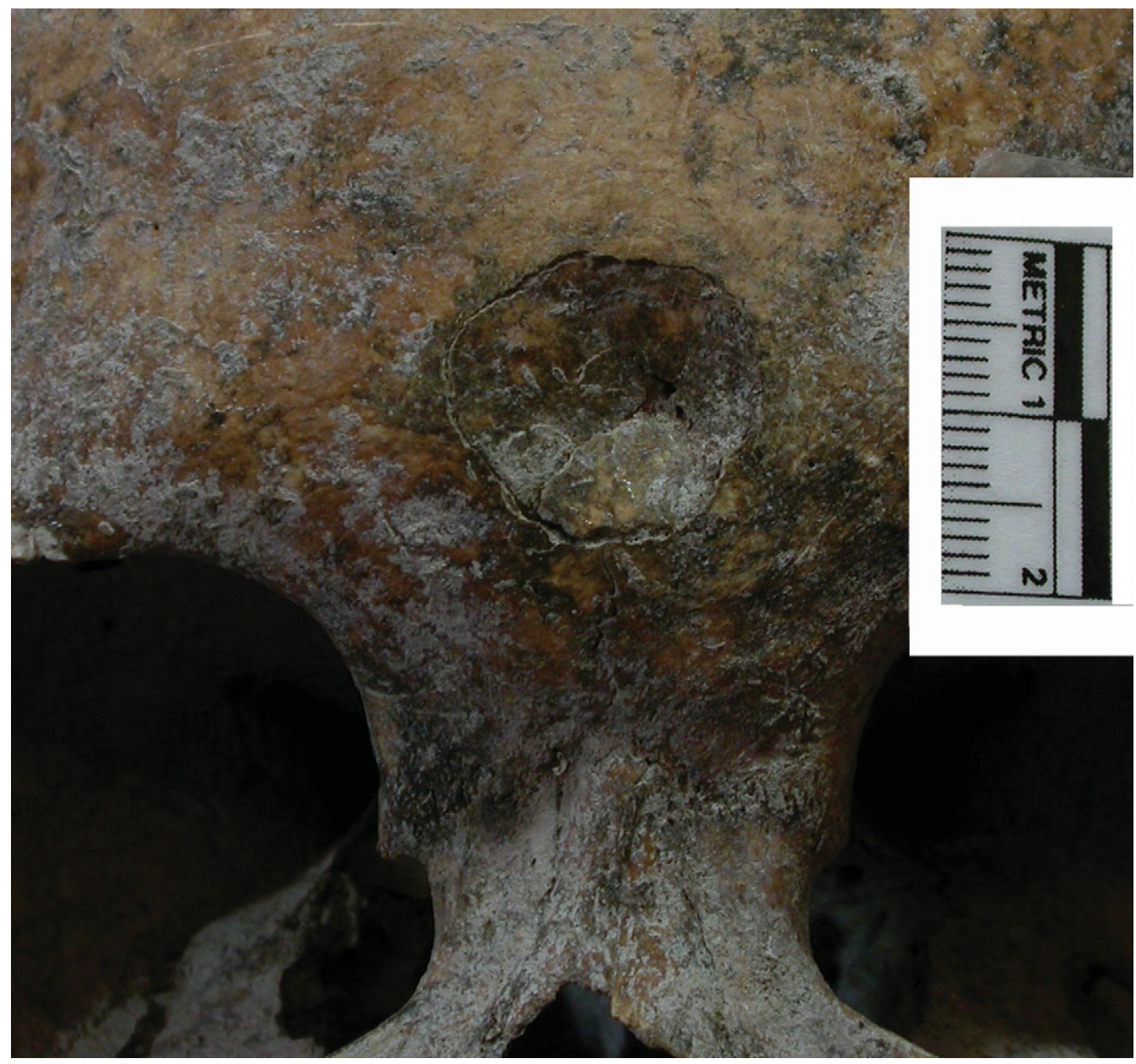

Figure 5. Perimortem blunt force trauma in the glabella of the frontal bone (adult female).

of some kind (cf. Walker 2001). It is further likely that the number of actual injuries suffered by the population was much higher than the skeletal evidence suggests, as ... most assaults cause soft-tissue injuries that would not be recorded in ancient skeletal material' (Walker 2001: 584).

The frequency of cranial trauma at Phum Snay can be confirmed as very high by comparison with other studies. A number of bioarchaeological studies have been published that include observations, but rarely frequencies, of trauma in prehistoric mainland Southeast Asia (Douglas 1996; Oxenham et al. 2001; Domett \& Tayles 2006; Pietrusewsky et al. 2006). Due to limited excavations, skeletal analyses from sites within Cambodia are particularly sparse. The skeletal remains of five pre-Angkorian sites have been analysed (Chhem et al. 2004; Domett 2005; Reinecke et al. 2009) with only two cases of cranial trauma reported: one undated from Koh Krabas (Wallwork 2006) and one at Angkor Borei dating to c. 200 BC-AD 400 (Pietrusewsky et al. 2006). 

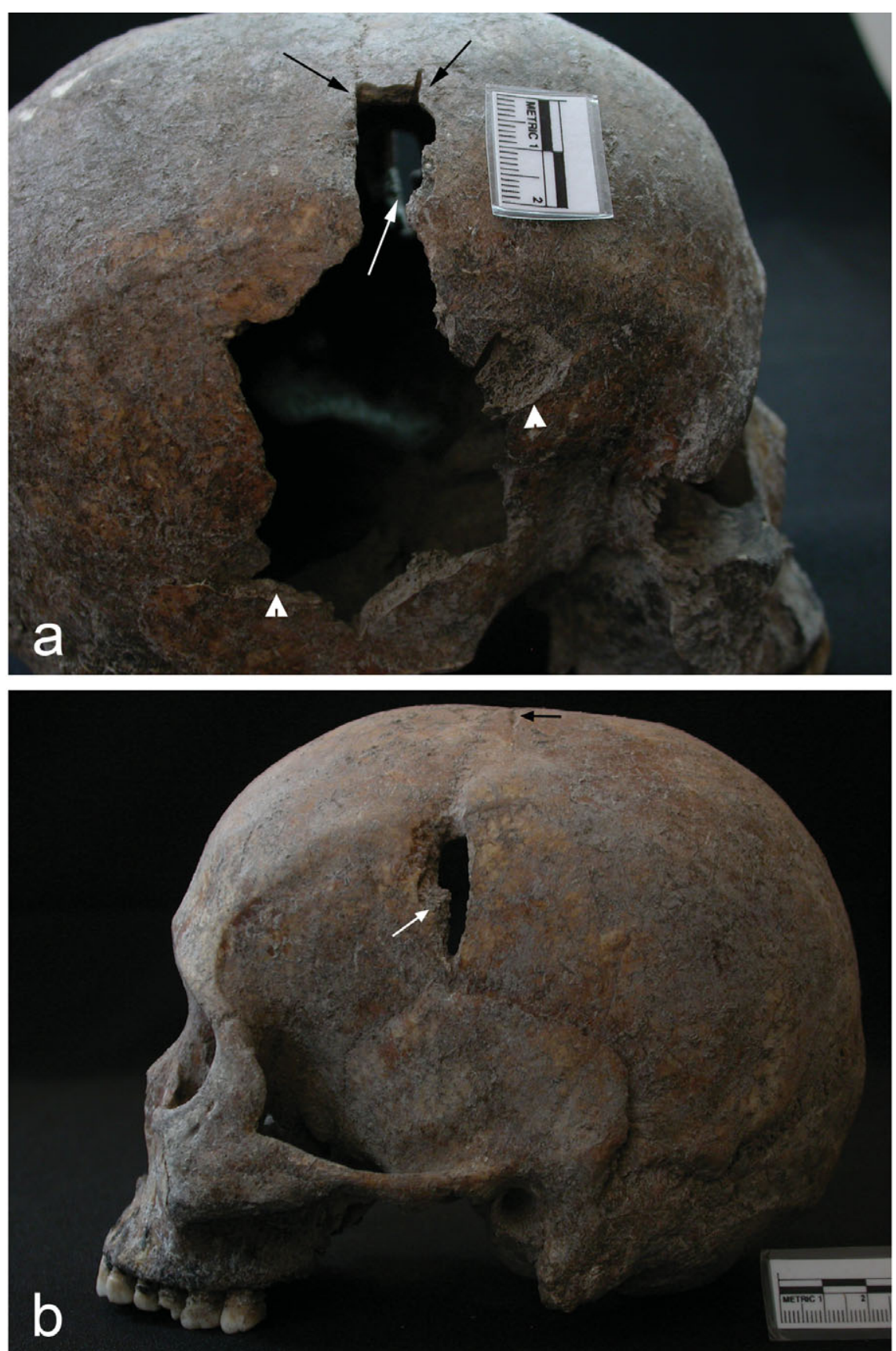

Figure 6. Perimortem trauma in WLC 73, adult, female: a) right lateral view shows two cut marks (black arrows), one on the coronal suture and one on the frontal bone, that have resulted in the fracturing of a large amount of bone of the parietal, frontal and temporal bones. Some of the fragments of the temporal bone were found inside the cranial vault during cleaning and two areas show distinctive perimortem ectocranial bone flaking exposing the diplöe underneath (white arrow heads). The white arrow in (a) indicates the hole on the left parietal that may be the exit wound indicated in (b) near the intersection of the coronal and sagittal sutures (white arrow). Bone has flaked off on the parietal. Note also the further unhealed SFT (cut mark) on the superior aspect of the parietal (black arrow). 
Contextual evidence from Phum Snay showing the potential for violence is considerable. A range of weapons were identified in many graves, including long iron swords and projectile points. The majority of individuals buried with weapons were male. The swords found in these graves were over $1 \mathrm{~m}$ in length and nearly $100 \mathrm{~mm}$ wide near the hilt, similar in form to the late medieval claymore swords of Scotland. Smaller short swords were also encountered in some burials. Caches of projectile points found in burials appear to be of two types: long, narrow points and broad, leaf-shaped points. Although not directly indicative of violence, ornamental shoulder decorations, epaulettes, were also found in the graves of young adult males (Figure 7). The epaulettes were fashioned from shaped pot rims and shoulders, and some had iron in the shape of buffalo horns attached to them. These were found in two burials at the shoulder of the skeleton and many looted examples were encountered. It is interesting to note that the marriage of martial and animal motifs is apparent on the walls of Angkor Wat where soldiers in Suryavarman II's army wear helmets depicting a range of different animals (Figure 8). Jacq-Hergoualc'h (2007: 85) states that 'perhaps these animal figures corresponded to the desire of the warriors to place themselves under the protection of this or that revered animal'. It may be that these animals are regional or clan signifiers. At Phum Snay buffalo iconography was very common, especially in the form of finger rings, on bronze bells and on epaulettes. Buffalo bones were also commonly encountered in male burials as a grave offering (O'Reilly et al. 2006b).

At Phum Snay looters reported finding skulls with bronze helmets; however, our excavations and subsequent excavations have not encountered such evidence. A shallow bronze bowl was found covering the right side of one female skull (O'Reilly et al. 2006b; O'Reilly \& Pheng 2001; O'Reilly 2004), similar to a discovery at Prohear in south-east Cambodia (Reinecke et al. 2009). It is possible that similar burial behaviour has been misinterpreted by the villagers as representing helmets. A helmet would protect the cranium to some degree, perhaps providing an explanation for the large number of healed injuries.

There is no doubt that during the Angkorian period, males were the primary combatant, as the bas-reliefs on temples such as Angkor Wat, Bayon and Banteay Chhmar illustrate. The trauma apparent at Phum Snay is a combination of blunt and sharp force but the large amount of healed trauma makes it difficult to match a specific weapon with the wounds (cf. Powers 2005). An examination of known weaponry from the later Angkorian period does not show a predominance of weapons that could inflict BFT. At Angkor Wat (early twelfth century) only lances and bucklers (small round shields), bows and arrows, sabres of various sizes, $p h k \bar{a}$ 'ks (curved handled weapons with an iron blade on the outside of the crux), knives and cutlasses of varying sizes are illustrated (Jacq-Hergoualc'h 2007). Clubs or blunt weapons are found nowhere in these reliefs. It is, of course, possible that in the intervening 700 years weapon technology evolved toward the predominant use of bladed weapons and projectiles, but swords and projectiles are in the repertoire of Phum Snay. If helmets were worn, it is possible that a sharp weapon may produce BFT injuries in a helmeted individual. While no analysis has been undertaken comparing the weapons of Phum Snay to those illustrated in the bas-reliefs of Angkor Wat or the later Jayavarman VII temples, comparisons have been made between these and weapons found at Dong Son, Vietnam. Dong Son is roughly contemporary with Phum Snay and the weapons found there bear a degree of similarity to later Khmer weapons (Goloubew 1929). The prevalence 

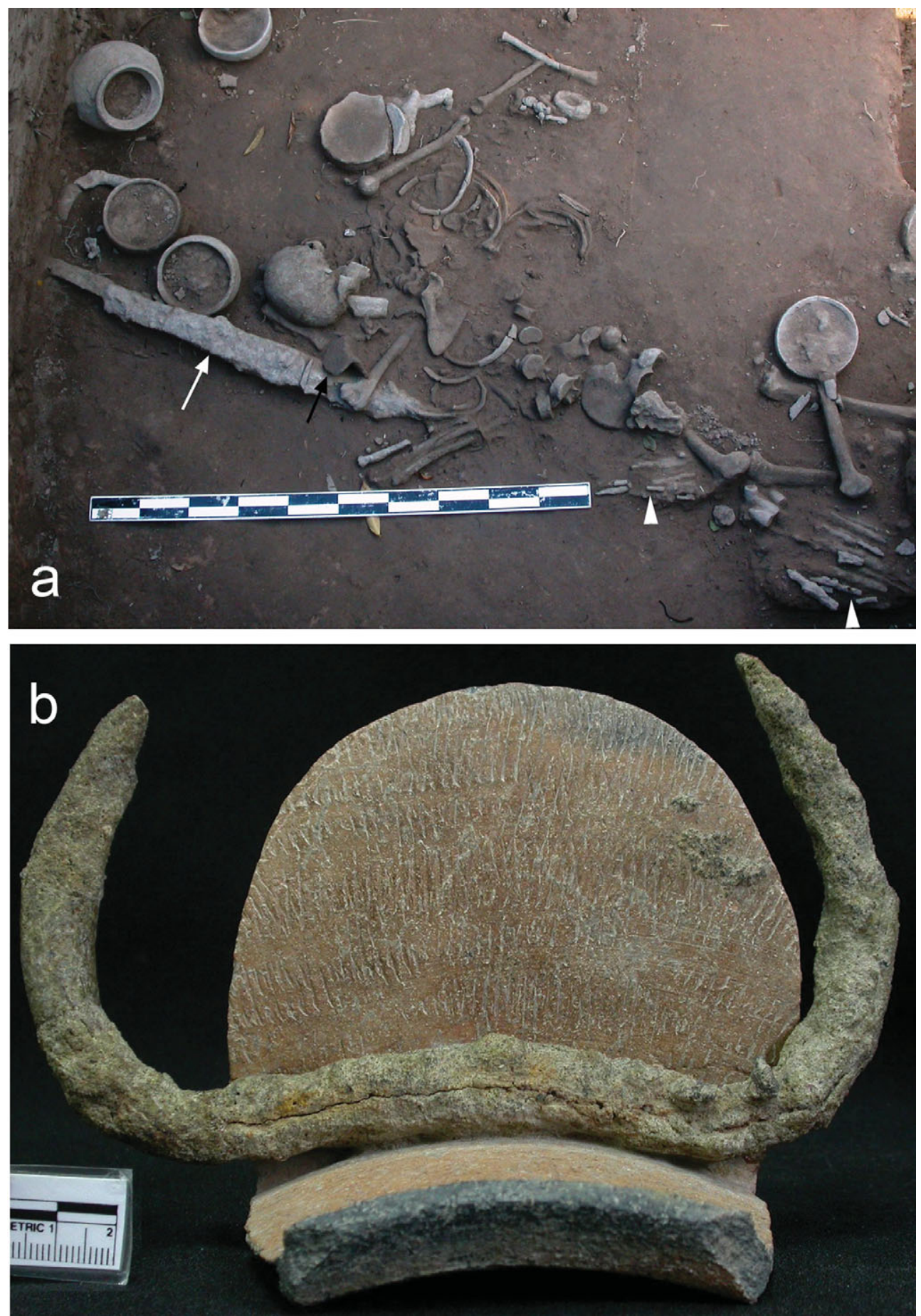

Figure 7. Archaeological evidence of warfare and weaponry at Phum Snay: a) adult male burial with a long iron sword (white arrow), two caches of projectile points (white arrow heads), and a ceramic epaulette in the shoulder region (black arrow); b) ceramic epaulette with iron horns (unprovenanced artefact). 

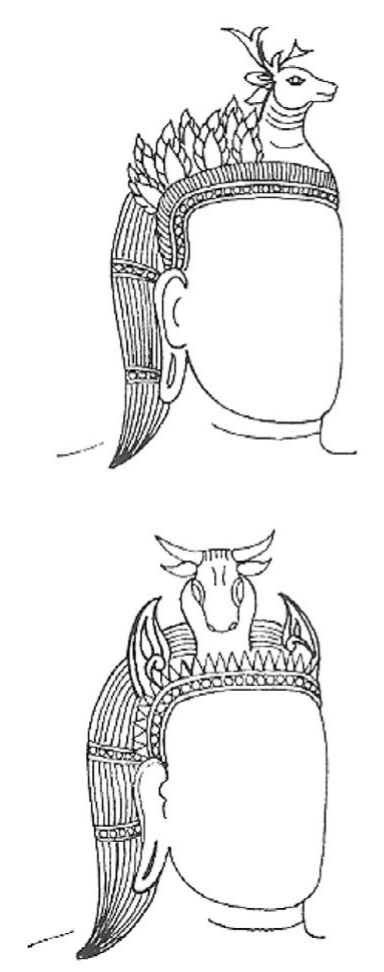

M
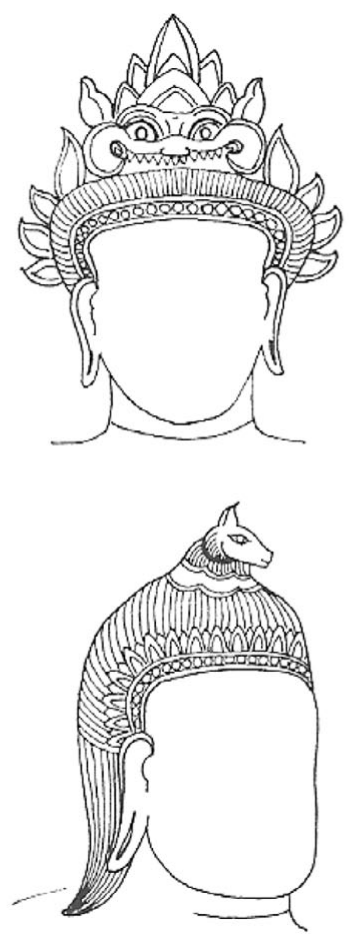

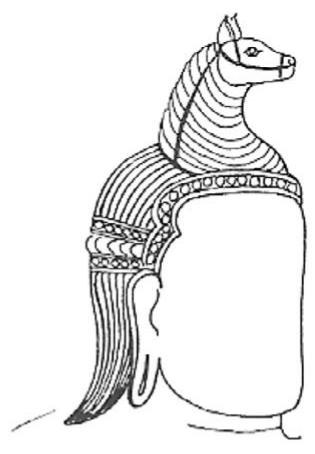

$N$

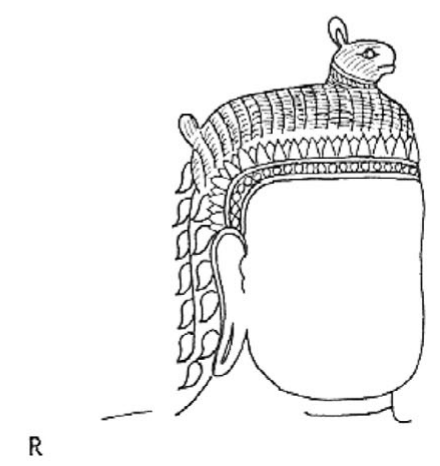

Figure 8. Drawings of bas-relief at Angkor Wat showing soldiers in animal-motif headdresses (Jacq-Hergoualc'h 2007).

of BFT on crania from Phum Snay may suggest a different type of warfare is represented in the Snay dataset.

In terms of material culture, the Iron Age in north-west Cambodia has much in common with the late Iron Age in north-east Thailand. Therefore, a comparison of Phum Snay with Thai Iron Age sites such as Noen U-Loke and Ban Non Wat seems valid (Higham \& Thosarat 2006; O'Reilly et al. 2006b; Higham et al. 2007). As in Cambodia, direct evidence of violent trauma from prehistoric Thailand is also currently sparse. Neolithic Khok Phanom Di had only one male affected (Tayles 1999). Douglas (1996) as well as Pietrusewsky and Douglas (2002) noted cranial trauma frequencies of 2.5 per cent for Non Nok Tha (c. 1500-1000 BC) and 8.3 per cent at Ban Chiang (c. 2100 BC-AD 200). Overall, Pietrusewsky and Douglas (2002) found males were more often affected by trauma than females, but suggest the majority are the result of accidental injury.

A study comparing four prehistoric Thailand sites found a tenfold increase in long bone fractures between the Neolithic and Bronze Age (Domett \& Tayles 2006). There has, however, been no substantial archaeological evidence of weaponry that would support a hypothesis of increased warfare during the Bronze Age in this region. An unusual case of possible perimortem trauma from Iron Age Noen U-Loke in north-east Thailand is that of an older female who exhibited a large cut completely through the cranium and mandible with other perimortem lesions suggesting blows were also inflicted to the head (Tayles 2003). 
Also at this site a young adult male was found with an iron projectile point located in situ adjacent to his spine (Tayles et al. 2007).

Higham notes that there is some evidence for intercommunity conflict and hierarchy at the site of Noen U-Loke:

'Friction between different groups is a stimulus to the rise of leaders. Even in the second mortuary phase [at Noen U-Loke], we find evidence for iron and bronze weaponry, but the most compelling evidence for fighting is to be found in the distribution of iron projectile points... Such arrowheads dramatically increased in frequency in the later contexts, a potential indication of conflict'(Higham 2002: 208).

A Thai site, further to the north, Ban Wang Hai, contains some military artefacts including an iron sword approximately $450 \mathrm{~mm}$ in length (Pautreau et al. 2003). Bronson (1991) has noted that $[\mathrm{t}]$ he appearance of iron ... seems to be accompanied in some parts of [Thailand] by significant alterations of the societies and economies involved'. It is difficult to tell if the introduction of this new technology was related to apparent changes in the socio-economic fabric of Southeast Asian societies but there were a number of changes, at least in north-east Thailand, at the beginning of the Iron Age (c. $500 \mathrm{BC})$, including a proliferation of habitation sites and an increase in public labour efforts. Also, there may have been centralisation of ceramic production, represented by Phimai tradition pottery, and an increase in craft specialisation (O’Reilly 2000).

It is clear that the level of violent trauma at Phum Snay was exceptionally high (see also Jurmain 1999). What was the impetus for such conflict during the pre-Angkorian period?

One contributing factor in the development of hierarchical structures may be found in an examination of control of exchange routes or export commodities, such as salt, fish or metals. It is also possible that competition over access to exotic exchange items developed during the Iron Age, evidenced by the increase in military paraphernalia found in interments (Sørenson 1973; Wilen 1987; Higham \& Thosarat 1998; Pautreau \& Mornais 1998). Also important is the morphology of many of the Mun Valley Iron Age sites. These sites are surrounded, in many cases, by multiple moats and banks, sometimes up to $200 \mathrm{~m}$ wide and evidence of sophisticated water control devices that may also have had a defensive function. This evidence, in conjunction with that for increased iron weaponry, would seem to indicate a rise in social friction in north-east Thailand during the Iron Age. This is now also evident for Iron Age, north-west Cambodia, with added support from the human remains.

\section{Conclusion}

The analysis of the cranial dataset from Phum Snay indicates that over 23 per cent of individuals were affected by some form of cranial trauma, with males more commonly affected than females, from which most recovered. It is likely that this trauma was the result of violence. This high frequency is unparalleled in Southeast Asia where the skeletal evidence to date has indicated much lower rates of trauma. The reasons for this discrepancy are difficult to determine but an attendant abundance of military paraphernalia in the graves of the prehistoric people of Phum Snay may offer some corroboration. 
There are indications that only a few hundred years after the date of the cemetery at Snay there were significant and powerful polities in existence in the north-west of Cambodia. Given this fact and the site's proximity to Angkor, shown to have been a prominent religious and political centre, it is not surprising that the population felt the need to arm themselves. The fact that they may have needed to use these arms is, perhaps, indicated by the extent of cranial trauma seen in this dataset.

\section{Acknowledgements}

Thanks to staff and students at RUFA, Phnom Penh; the Ministry of Culture and Fine Arts of Cambodia; to Dr Christophe Pottier at the l'Ecole Française d'Extrême-Orient in Siem Reap for lab space; to Preah Maha Vimaladhamma Pin Sem Sirisuvanno at Wat Rajabo in Siem Reap and Phum Snay elders at Wat Leu for access to the specimens, and to the people of Phum Snay for their cooperation; to Eileen Lustig, Louise Shewan, Martin Carver, Chris Knüsel and the anonymous reviewer for comments.

Grant sponsorship: James Cook University; Australian Academy of Humanities Fieldwork Fellowship, the Center for Khmer Studies.

\section{References}

Aymonier, E. 1904. Le Cambodge. Volume 3: le groupe d'Angkor et l'histoire. Paris: Leroux.

BRIGGs, L. 1951. The ancient Khmer Empire (Transactions of the American Philosophical Society 41). Philadelphia (PA): The American Philosophical Society.

BRONSON, B. 1991. Theoretical aspects of bronze and iron use in ancient Southeast Asia. Paper presented at the Conference on The Higher Bronze Age of Southeast Asia and South China, Hua Hin, Thailand.

BuiKSTRA, J.E. \& D.H. UbELAKER (ed.). 1994. Standards for data collection from human skeletal remains. Fayetteville (AR): Arkansas Archaeological Survey.

BYERS, S.N. 2002. Introduction to forensic anthropology: a textbook. Boston (MA): Allyn \& Bacon.

CHetwin, J. 2001. War before Angkor: the evidential and theoretical context of warfare in prehistoric Thailand. Unpublished PhD dissertation, University of Otago.

Chhem, R., S.K. Venkatesh, S-C. Wang, K-M. Wong, F.J. Ruhli, P.Y. Siew, K. LATinis \& C. POTTIER. 2004. Multislice computed tomography of two 2000-year-old skeletons in a soil matrix from Angkor, Cambodia. Canadian Association of Radiologists Journal 55: 235-41.

Clark, J. (ed.) 2007. Bayon: new perspectives. Bangkok: River.

CoEDÉs, G. 1932. Etudes cambodgiennes - Banteay Chmar, Bayon, Banteay Srey. Bulletin de l'Ecole française d'Extrême-Orient 32: 71-112.
Coedés, G. 1937-66. Les inscriptions du Cambodge. Hanoi \& Paris: Ecole française d'Extrême Orient.

- 1968. The indianized states of Southeast Asia. Honolulu (HI): University of Hawaii Press.

DOMETT, K.M. 2005. The skeletal remains from Krasaing Thmei, Banteay Meanchey Province, Cambodia. Report to the Royal University of Fine Arts, Phnom Penh.

DometT, K.M. \& D.J.W. O’ReiLly. 2009. Health in pre-Angkorian Cambodia: a bioarchaeological analysis of the skeletal remains from Phum Snay. Asian Perspectives 48: 56-78.

DometT, K.M. \& N. TAYLES. 2006. Adult fracture patterns in prehistoric Thailand: a biocultural interpretation. International Journal of Osteoarchaeology 16: 185-99.

DougLAS, M.T. 1996. Paleopathology in human skeletal remains from the pre-metal, bronze and iron ages, northeastern Thailand. Unpublished $\mathrm{PhD}$ dissertation, University of Hawaii.

Evans, D., C. Pottier, R. Fletcher, S. Hensley, I. Tapley, A. Milne \& M. BarbetTi. 2007. A comprehensive archaeological map of the world's largest preindustrial settlement complex at Angkor, Cambodia. Proceedings of the National Academy of Sciences 104: 14277-82.

FINOT, L. 1925. Inscriptions d'Angkor. Bulletin de l'Ecole française d'Extrême-Orient 25: 289-416.

GERINI, G.E. 1909. Researches on Ptolemy's geography of eastern Asia (further India and Indo-Malay archipelago) (Asiatic Society mongraphs 1). London: Royal Asiatic Society.

GoloubEW, V. 1929. L'âge du bronze au Tonkin et dans le nord-Annam. Bulletin de I'Ecole française d' Extrême-Orient 29: 1-46. 
HigHAM, C.F.W. 2002. Early cultures of mainland Southeast Asia. Bangkok: River Books.

Higham, C.F.W. \& R. Thosarat. 1998. Noen U-Loke and the implications for the origins of early states. Bulletin of the Indo-Pacific Prehistory Association 17: 44.

- 2006. Ban Non Wat: the first three seasons, in E.A. Bacus, I.C. Glover \& V.C. Pigott (ed.) Uncovering Southeast Asia's past: selected papers from the 10th International Conference of the European Association of Southeast Asian Archaeologists: the British Museum, London, 14-17 September 2004: 98-104. Singapore: NUS Press.

Higham, C.F.W., A. Kijngam \& S. Talbot. 2007. The origins of the civilization of Angkor. Volume 2: the excavation of Noen U-Loke and Non Muang Kao. Bangkok: Fine Arts Department of Thailand.

JACQ-HergoualC'H, M. 2007. The armies of Angkor: military structure and weaponry of the Khmers. Bangkok: Orchid Press.

JACQUES, C. 1986. The royal city of Angkor and the State, as glimpsed in the inscriptions (9th to12th centuries). Lecture at Oxford: 1-14.

JURMAIN, R. 1999. Stories from the skeleton: behavioral reconstruction in human osteology. Amsterdam: Gordon \& Breach.

Kaufman, M.H., D. Whitaker \& J. MCTaVish. 1997. Differential diagnosis of holes in the calvarium: application of modern clinical data to palaeopathology. Journal of Archaeological Science 24: 193-218.

Le Bonheur, A. \& J.P. Poncar. 1993. Of gods, kings, and men: bas-reliefs of Angkor Wat and Bayon. London: Serindia.

LOVELL, N.C. 1997. Trauma analysis in paleopathology. Yearbook of Physical Anthropology 40: 139-70.

- 2008. Analysis and interpretation of skeletal trauma, in M.A. Katzenberg \& S.R. Saunders (ed.) Biological anthropology of the human skeleton: 341-86. New York: Wiley.

O’Reilly, D.J.W. 2000. From the Bronze Age to the Iron Age in Thailand: applying the heterarchical approach. Asian Perspectives 39: 1-19.

- 2004. Excavations at Phum Snay, Cambodia. Bulletin of the Indo-Pacific Prehistory Association 24: 129-32.

O'ReIlly, D.J.W. \& S. Pheng. 2001. Recent excavations in north-west Cambodia. Antiquity 75: 265-6.

O’Reilly, D.J.W., T. Chanthourn \& K. DometT. 2004. A preliminary report on the excavation of an Iron Age cemetery at Phum Snay, Banteay Meanchey, Cambodia, 2003. Udaya Journal 5: 219-25.
O’Reilly, D.J.W., K. Domett \& S. Pheng. 2006 a. The excavation of a late prehistoric cemetery in northwest Cambodia. Udaya 7: 207-222.

O’Reilly, D.J.W., A. VON DEN Driesch \& V. VOeum. 2006b. Archaeology and archaeozoology of Phum Snay: a late prehistoric cemetery in northwestern Cambodia. Asian Perspectives 45: 188-211.

ORTNER, D.J. 2003. Identification of pathological conditions in human skeletal remains. San Diego (CA): Academic Press.

OXenham, M.F., I. Walters, L.C. NGUyen \& K.T. NGUYEN. 2001. Case studies in ancient trauma: mid-Holocene through metal periods in Northern Vietnam, in M. Hennenberg (ed.) Causes and effects of human variation: 83-102. Adelaide: Australasian Society for Human Biology, University of Adelaide.

Pautreau, J-P. \& P. Mornais. 1998. Ban Wang Hi (Thailande) Travaux 1998. Journée Préhistorique et Protohistorique de Bretagne 1998: 11-16.

Pautreau, J.-P., P. Mornais \& T. Doy-Asa. 2003. Ban Wang Hai: excavations of an Iron-Age cemetery in northern Thailand. Bangkok: Silkworm.

Pietrusewsky, M. \& M.T. Douglas. 2002. Ban Chiang, a prehistoric village site in northeast Thailand. 1: the human skeletal remains (Thai archaeology monograph series 1). Philadelphia (PA): University of Pennsylvania Museum of Archaeology and Anthropology.

Pietrusewsky, M., R. IKehara-Quebral \& M.T. DOUGLAS. 2006. The bioarchaeology of the Vat Komnou cemetery, Angkor Borei, Cambodia. Bulletin of the Indo-Pacific Prehistory Association 26: 86-97.

Powers, N. 2005. Cranial trauma and treatment: a case study from the medieval cemetery of St Mary Spital, London. International Journal of Osteoarchaeology 15: 1-14.

Quatrehomme, G. \& M.Y. IşCAN. 1997. Postmortem skeletal lesions. Forensic Science International 89: 155-65.

ReIneCKe, A., L. Vin \& S. SENG. 2009. The first golden age of Cambodia: excavation at Prohear. Bad Langensalza: Embassy of the Federal Republic of Germany, Phnom Penh.

Sørenson, P. 1973. Prehistoric iron implements from Thailand. Asian Perspectives 16: 134-73.

STARK, M. 2004. Pre-Angkorian and Angkorian Cambodia., in I. Glover. \& P. Bellwood (ed.) Southeast Asia from prehistory to history: 89-119. New York: Routledge Curzon Press. 


\section{Bioarchaeological evidence for conflict in Iron Age north-west Cambodia}

STODDER, A.L.W. 2008. Taphonomy and the nature of archaeological assemblages, in M.A. Katzenberg \& S.R. Saunders (ed.) Biological anthropology of the human skeleton: 71-114. New York: Wiley.

TAYLES, N. 1999. The excavation of Khok Phanom Di, a prehistoric site in central Thailand. Volume 5: the people (Reports of the Research Committee of the Society of Antiquaries of London 61). London: Society of Antiquaries of London.

- 2003. Murder or mortuary behaviour? An Iron Age enigma from northeast Thailand. International Journal of Osteoarchaeology 13: 197-206.

Tayles, N., S. Halcrow \& K. Domett. 2007. The people of Noen U-Loke, in C.F.W. Higham, A. Kijngam \& S. Talbot (ed.) The origins of the civilization of Angkor. Volume 2: the excavation of Noen U-Loke and Non Muang Kao: 244-304. Bangkok: Fine Arts Department of Thailand.

TUAN-LiN, M. 1876. Ethnographie des peuples e trangers à la Chine. Geneva: Georg.
WALKER, P.L. 2001. A bioarchaeological perspective on the history of violence. Annual Review of Anthropology 30: 573-96.

WALLWORK, C. 2006. An osteological investigation into unprovenenced remains from Koh Krabas, northwest Cambodia. Canberra: Australian National University, School of Archaeology and Anthropology.

WheATLEY, P. 1961. The Golden Khersonese: studies in the historical geography of the Malay Peninsula before $A D$ 1500. Kuala Lumpur: University of Malaya Press.

WILEN, R. 1987. Excavation and site survey in the Huay Sai Khao Basin, northeastern Thailand. Bulletin of the Indo-Pacific Prehistory Association 7: 94-117.

Wolters, O.W. 1974. North-western Cambodia in the seventh century. Bulletin of the School of Oriental and African Studies, University of London 37: 355-84. 